\title{
HUBUNGAN POLA ASUH ORANGTUA DAN KEMANDIRIAN ANAK
}

\author{
Kustiah Sunarty \\ Bimbingan dan Konseling/Ilmu Pendidikan \\ Fakultas Ilmu Pandidikan Universitas Negeri Makassar \\ ksunarty@gmail.com
}

\begin{abstract}
This study examines patterns of parenting and the child's self reliance. The research problem is whether there is a relationship between parenting parents and the child's self reliance? The research questions: (1) which type of parenting is now used parents in an effort to increase the child's self reliance? (2) Which type of parenting that can increase the child's self reliance? (3) Is there a relationship between parenting parents and the child's self reliance? The purpose of research is to determine: (1) the type of parenting parents present in order to increase the child's self reliance, (2) the type of parenting can increase the child's self reliance, (3) the relationship between parenting parents and the child's self reliance. The study population is the students of Junior High School in the city of Makassar. Data were collected through scale/questionnaire. Data were analyzed with descriptive statistics and inferential statistics. The results showed that: (1) the type of parenting parents used today to improve their self-reliance, respectively: positive parenting, democratic, authoritarian, permissive, negative/ unhealthy, and neglectful; (2) positive parenting and democratic can increase the child's self reliance, and 3) there is a positive and significant relationship between parenting parents and the child's self reliance.
\end{abstract}

Keywords: parenting, self reliance, relationships parenting and self-reliance

\begin{abstract}
ABSTRAK
Penelitian ini menelaah pola asuh orangtua dan kemandirian anak. Permasalahan penelitian adalah apakah ada hubungan antara pola asuh orangtua dan kemandirian anak?. Pertanyaan penelitian: (1) jenis pola asuh manakah sekarang ini yang digunakan orangtua dalam upaya meningkatkan kemandirian anak?, (2) jenis pola asuh orangtua manakah yang dapat meningkatkan kemandirian anak?, dan 3) adakah hubungan antara pola asuh orangtua dan kemandirian anak?. Tujuan penelitian adalah untuk mengetahui: (1) jenis pola asuh orangtua sekarang ini dalam upaya meningkatkan kemandirian anak, (2) jenis pola asuh yang dapat meningkatkan kemandirian anak, dan (3) hubungan antara pola asuh orangtua dan kemandirian anak. Populasi penelitian adalah siswa SMP Negeri di kota Makassar. Data dikumpulkan melalui skala/angket. Data dianalisis dengan statistik deskriptif dan statistik infrensial. Hasil penelitian menunjukkan bahwa: (1) jenis pola asuh yang digunakan orangtua sekarang ini dalam meningkatkan kemandirian anaknya, secara berturut-turut: pola asuh positif, demokratis, otoriter, permisif, negatifltidak sehat, dan penelantar; (2) pola asuh positif dan demokratis dapat meningkatkan kemandirian anak, dan 3) ada hubungan yang positif dan signifikan antara pola asuh orangtua dan kemandirian anak.
\end{abstract}

Kata Kunci: Pola asuh, kemandirian, hubungan pola asuh dan kemandirian 


\section{PENDAHULUAN}

Salah satu tujuan pendidikan nasional adalah kemandirian. Hal ini tercantum dalam Undang-Undang Sistem Pendidikan Nasional (UURI No. 20, 2003) dikemukakan:

Tujuan pendidikan nasional, yaitu meningkatkan potensi peserta didik agar menjadi manusia yang beriman dan bertakwa kepada Tuhan Yang Maha Esa, berakhlak mulia, sehat, berilmu, cakap, kreatif, mandiri, dan menjadi warga negara yang demokratis serta bertanggung jawab.

Kemandirian merupakan aspek yang berkembang dalam diri setiap individu, yang bentuknya sangat beragam, tergantung pada proses perkembangan dan proses belajar yang dialami masing-masing individu. Driyarkara (Sugito, 2013) mengemukakan bahwa kemandirian merupakan kekuatan internal individu yang diperoleh melalui proses individuasi. Oleh karena itu, kemandirian mengandung pengertian memiliki suatu penghayatan/ semangat untuk menjadi lebih baik dan percaya diri, mengelola pikiran untuk menelaah masalah dan mengambil keputusan untuk bertindak, disiplin dan tanggung jawab serta tidak bergantung kepada orang lain.

Pribadi yang mandiri, dicirikan dengan perilaku bersahabat dan intim, perilakunya dicirikan dengan kemampuan mengambil keputusan sendiri terhadap aktivitas-aktivitasnya, dalam kehidupan sehari-hari tanpa meminta tolong kepada orang lain (James, 2002); mampu memikul tanggung jawab, dan mempunyai emosi yang stabil (Darajad, 1982).

Mencermati ciri-ciri perilaku mandiri seperti tersebut, maka mestinya tidak ada lagi perilaku menyimpang, seperti malas belajar, tawuran, nyontek, minum-minuman keras, narkoba, dan semacamnya. Namun, secara kenyataan masih banyak keluhan dari para guru, guru $\mathrm{BK} /$ Konselor, yang mengatakan bahwa siswa-siswa malas belajar, siswa belajar jika diperintah, belajar jika ada ujian keesokan harinya, gembira jika guru tidak mengajar, ataukah ribut di kelas jika ada jam lowong, terlalu santai, malas mengerjakan tugas sekolah, sering masuk terlambat dan pulang terlambat, banyak siswa yang berkeliaran di luar sekolah pada jam-jam sekolah, tawuran, dan unjuk rasa. Bahkan, hampir setiap hari di media sosial, baik cetak maupun elektronik menayangkan perilaku- perilaku siswa sangat jauh dari perilaku anak mandiri. Hasil penelitian Komaruddin (2005) mengungkapkan tentang ketidakmandirian siswa ditandai dengan sikap-sikap yang tidak bertanggung jawab, seperti: sering terlambat, tidak mengikuti pelajaran pada jam-jam tertentu, tidak memanfaatkan jam kosong untuk belajar, tidak membantu orangtua dengan kesadaran sendiri, kurang disiplin dalam belajar, dan kurang aktif dalam kegiatan di masyarakat. Hasil penelitian Marjohan (2009) menemukan bahwa siswa gemar berkeliaran pada jam belajar, pergi sekolah hanya untuk ngobrol dengan teman-teman, pergi sekolah hanya sebagai mode, sekolah untuk hura-hura, sikap belajar santai, dan belajar jika disuruh. Begitu pula Sutopo (2007) menemukan bahwa ketidakmandirian siswa ditandai dengan ketidaksiapan belajar, kebiasaan belajar yang kurang baik, seperti bergantung pada "LKS", dan menyontek pada saat ujian.

Berkaitan dengan contoh-contoh kasus tersebut, banyak faktor yang dapat memengaruhi perilaku mandiri. Ali \& Asrori (2008) mengemukakan faktor-faktor dari dalam diri anak, seperti gen/ keturunan, urutan kelahiran, kondisi fisik, bakat dan potensi intelektual, kematangan, dan jenis kelamin anak; sedangkan faktor-faktor dari luar diri anak, seperti pola asuh orangtua, sistem pendidikan sekolah, dan sistem kehidupan masyarakat. Dari sejumlah faktorfaktor tersebut, yang akan dikaji lebih lanjut adalah faktor pola asuh orangtua, dengan pertimbangan terdapat sejumlah hasil penelitian mengungkapkan bahwa kemandirian anak sangat dipengaruhi oleh pola asuh orangtuanya, yang bermula dari proses tumbuh kembang anak.

Bertolak dari fenomena-fenomena tersebut maka dirumuskan permasalahan penelitian sebagai berikut: 1) jenis pola asuh manakah sekarang ini yang digunakan oleh orangtua dalam upaya meningkatkan kemandirian anaknya? 2) jenis pola asuh orangtua manakah yang dapat meningkatkan kemandirian anak?, dan 3) adakah hubungan antara pola asuh orangtua dan kemandirian anak?

Mengenai tinjauan pustaka mengenai pola asuh dikemukakan oleh James (2002) bahwa pola asuh diartikan sebagai parenting cara orangtua berinteraksi dengan anak, cara orangtua berperilaku sebagai model di hadapan anakanaknya cara orangtua memberikan kasih sayang, menanggapi dan membantu anak mengatasi masalahnya, hangat, terbuka, mau 
mendengarkan secara aktif, dan realistik (Daradjad, 1982; Gordon, 2000).

Jadi, pola asuh orangtua dapat diartikan sebagai perlakuan orangtua terhadap anak dalam bentuk merawat, memelihara, mengajar, mendidik, membimbing, melatih, yang terwujud dalam bentuk pendisiplinan, pemberian tauladan, kasih sayang, hukuman, ganjaran, dan kepemimpinan dalam keluarga melalui ucapanucapan dan tindakan-tindakan orangtua.

Tentang jenis-jenis pola asuh orang tua dapat dikenali adanya pola asuh otoriter, yang ditunjukkan dengan perilaku orangtua yang cenderung menetapkan standar yang mutlak harus dituruti, menuntut kepatuhan, mendikte, hubungan kurang hangat, kaku, dan keras. Dampaknya: muncul perilaku agresif sangat tinggi atau sangat rendah, cemas dan mudah putus asa, penakut, pendiam, tertutup, tidak berinisiatif, berkepribadian lemah, cemas dan terkesan menarik diri, membangkang, tak dapat merencanakan sesuatu, tingkah laku pasif dan cenderung menarik diri, sehingga menjadikan anak tidak mandiri (Gordon, 2000; James, 2002; Pratt, 2004).

Pola asuh orangtua otoritative adalah perilaku orangtua yang mengontrol dan menuntut tetapi dengan sikap yang hangat, komunikasi dua arah antara orangtua dan anak yang dilakukan secara rasional, dan kontrol positif. Dampaknya: anak memperlihatkan perilaku berani, lebih giat, dan lebih bertujuan, mandiri, dapat mengontrol diri, hubungan baik dengan teman-teman, mampu menghadapi stres, minat terhadap hal-hal yang baru, dan kooperatif terhadap orang lain, aktif, tidak takut gagal, spontan (Santrock, 2007; Papalia, 2008).

Pola asuh permisif, bersifat children centered yakni cara orangtua memperlakukan anak sesuai dengan kemauan anak atau keputusan di tangan anak. Dampaknya: anak impulsif, agresif, manja, kurang mandiri, kurang percaya diri, selalu hidup bergantung, salah bergaul, rendah diri, nakal, kontrol diri buruk, egois, suka memaksakan keinginan, kurang bertanggungjawab, berperilaku agresif dan antisosial (Gordon, 2000; Santrock, 2007; Papalia, 2008).
Pola asuh orangtua penelantar ditunjukkan dengan perilaku orangtua yang tampak dalam ucapan dan tindakan yang sering mengabaikan anak, baik secara fisik, maupun psikis. Dampaknya: anak merasa tidak berguna, tidak berdaya, apatis, tidak diterima, terbuang dari keluarga, impulsif, agresif, kurang bertanggung jawab, tidak mau mengalah, harga diri yang rendah, sering bermasalah dengan temannya, dan tidak mandiri (Papalia, 2008; dan Thalib, 2010).

Pola asuh orangtua positif/sehat ialah perlakuan orangtua kepada anak-anaknya yang dapat dikenali melalui ucapan dan tindakan orangtua yang berdampak baik bagi perkembangan kepribadian/kemandirian anak, yang tampak pada pola asuh orangtua: reasonable, encouraging, concistent, peace making, caring, relaxed, dan responsible. Dampaknya: Reasonable parents, memberikan alasan logis, menimbulkan rasa percaya diri tinggi; Encouraging parents, mendorong dan melakukannya sendiri, menimbulkan harga diri yang tinggi.; Concistent parents, menjaga/ memelihara ucapan dan tindakan yang sama pada situasi dan kondisi yang sama, membuat anak menjadi tegas, tangguh, percaya kepada kemampuan diri; Peace making parents: memberikan tauladan yang baik, membuat anak berperilaku baik dan meniru dengan suka rela, tanpa tekanan; Caring parents): memperhatikan dan mendengar ungkapan perasaan anak dapat membangkitkan kepercayaan dan harga diri yang tinggi; Relaxed parents): memberikan kebebasan kepada anak dalam bertindak, sehingga anak merasa dihargai; Responsible parents: memberi kepercayaan dan kebebasan, sesuai dengan kebutuhan anak, membelajarkan anak berani menanggung risiko dari suatu perbuatan yang dilakukannya (Gordon, 2000; James, 2002).

Pola asuh negatif .ialah perlakuan orangtua yang dapat dikenali melalui ucapan dan tindakannya yang berdampak buruk bagi perkembangan kepribadian/ kemandirian anak, tampak dalam pola asuh orangtua:. Overly critical, Overly protective, Inconcistent, Argumentative, Uninvolved, Super-organized, dan Emotionally needy. Dampaknya: Overly 
critical parents, cenderung menjadi anak penurut, berbuat berdasar perintah, menjadikan anak takut mengambil keputusan sendiri dan tidak mandiri; Overly protective parents, cenderung menjadi tidak berdaya, tidak percaya diri, penurut dan tidak mandiri; Inconsistent parents, cenderung menjadi anak yang selalu bingung, ragu-ragu, tidak dapat memutuskan sendiri, dan tidak mandiri; Argumentative parent, cenderung menjadi penurut, tidak berdaya, apatis, selalu menghindar, tidak mandiri; Uninvolved parents, cenderung pasrah, menerima nasib, dan tidak bisa mandiri; Superorganized, cenderung tidak berdaya, apatis, penurut, tidak mampu mengambil keputusan sendiri, dan tidak mandiri; Emotionally needy, cenderung penurut, individualistik, kurang memiliki nilai sosial, dan tidak mandiri (Gordon, 2000; dan James, 2002).

Mengenai konsep dasar kemandirian dinyatakan bahwa pengertian kemandirian dalam bahasa sehari-hari adalah berdiri sendiri tanpa bergantung kepada orang lain. Daradjad (1982) mengemukakan kemandirian adalah kecenderungan melakukan sesuatu yang diinginkannya tanpa meminta tolong kepada orang lain, mengukur kemampuan untuk mengarahkan kelakuannya tanpa tunduk kepada orang lain, bertanggung jawab, dan mempunyai emosi yang stabil.

Jadi, kemandirian dapat diartikan sebagai kemampuan individu mengambil keputusan sendiri terhadap kebutuhan atau aktivitasnya sehari-hari. Pengambilan keputusan tersebut, didasarkan pada: (1) berpikir rasional/logis; (2) yakin dan percaya diri; (3) tegas/asertif; (4) empati; (5) fleksibel, terbuka, dan kooperatif dan (6) mampu memecahkan masalah dan bertanggung jawab

$$
\text { Mengenai faktor-faktor yang }
$$

memengaruhi kemandirian, yaitu: (1) Gen atau keturunan orangtua, (2) Pola asuh orangtua, (3) Sistem pendidikan di sekolah, dan (4) Sistem kehidupan di masyarakat (Ali \& Asrori 2008). Gen atau keturunan, memiliki kecenderungan menurun kepada anak. Pola asuh, cara mengasuh dan mendidik anak akan memengaruhi tingkat perkembangan kemandirian anak. Sistem pendidikan, sekolah yang tidak menlaksanakan demokrasi pendidikan, menenkankan indoktrinasi menghambat kemandirian anak. Sistem kehidupan, di masyarakat, yang terlalu menekankan pentingnya hirarki struktur sosial, kurang menghargai manifestasi potensi anak dalam kegiatan produktif, menghambat perkembangan kemandirian.

Tentang kemandirian anak usia SMP, Desmita (2009) mengemukakan anak usia SMP, masa remaja, suatu periode kehidupan di mana kapasitas untuk memperoleh dan menggunakan pengetahuan secara efisien mencapai puncaknya, otak mencapai kesempurnaan, pemikiran telah mencapai tahap pemikiran operasional formal Remaja mampu berpikir secara abstrak, hipotesis, dan idealistik serta merumuskan proposisi secara logis.

Berkaitan dengan pemikiran operasional formal remaja sudah memiliki kemampuan dalam hal: (1) pengambilan keputusan, (2) orientasi masa depan, (3) perkembangan kognisi sosial, (4) perkembangan penalaran moral, (5) Perkembangan proaktivitas, dan (6) perkembangan resiliensi (Papalia, 2008; Santrock, 2009).

Pengambilan keputusan, terutama berkaitan dengan masa depan, memilih teman, melanjutkan studi, mencari kerja/karir, dan aktivitas sehari-hari (Papalia, 2008). Orientasi masa depan berkisar pada tugas-tugas perkembangan yang dihadapi, terutama pendidikan. Perkembangan kognisi sosial, merupakan kemampuan berpikir secara kritis mengenai isu-isu dalam hubungan interpersonal, yang berkembang sejalan dengan usia dan pengalaman. Perkembangan penalaran moral, merupakan suatu pedoman dalam menemukan identitas diri, meningkatkan hubungan personal, dan menghindari konflik-konflik peran yang selalu terjadi dalam masa transisi. Masa proaktivitas, adalah kemampuan untuk memiliki kebebasan dalam memilih respon, mengambil inisiatif, dan bertanggung jawab (Desmita, 2009). 
Tujuan penelitian adalah untuk mengetahui: 1) jenis pola asuh yang digunakan oleh orangtua sekarang ini dalam upaya meningkatkan kemandirian anaknya, 2) jenis pola asuh yang dapat meningkatkan kemandirian anak, dan 3) hubungan antara pola asuh orangtua dan kemandirian anak. Hipotesis penelitian: ada hubungan antara pola asuh orangtua dan kemandirian anak.

\section{METODE PENELITIAN}

Pendekatan penelitian yang digunakan dalam penelitian ini adalah kuantitatif, jenis penelitian korelasional.

Ruang lingkup penelitian atau obyek penelitian terdiri atas dua variabel, yakni pola asuh orangtua dan kemandirian anak.

Definisi operasional variabel penelitian mengenai Pola asuh orangtua adalah

a. Pola asuh otoriter, ditunjukkan dengan perilaku orangtua yang cenderung menetapkan standar yang mutlak harus dituruti, tanpa syarat.

b. Pola asuh otoritative (demokratis), ucapan dan tindakan orangtua yang rasional, bertanggung jawab, terbuka, penuh pertimbangan, obyektif, realistis, dan fleksibel.

c. Pola asuh permisif ucapan dan tindakan orangtua membiarkan, melindungi berlebihan, memberikan kebebasan pada anak tanpa control.

d. Pola asuh penelantar, ucapan dan tindakan orangtua mengabaikan dan menolak keberadaan anak.

e. Pola asuh positif, ucapan dan tindakan orangtua yang pantas, selalu mendorong, konsisten, selalu menyejukkan, merawat, rileks, dan bertanggung jawab.

f. Pola asuh negatif, ucapan dan tindakan orangttua yang serba mengkritik, melindungi berlebihan, selalu berubah-ubah, mendebat, mengabaikan, serba mengatur, dan menuntut perhatian emosional secara berlebihan.

Defenisi operasional kemandirian adalah kemampuan anak mengambil keputusan sendiri terhadap aktivitasnya, yang dikenali melalui kemampuannya dalam hal: (1) berpikir rasional/logis; (2) menumbuhkan keyakinan dan kepercayaan diri; (3) memiliki ketegasan; (4) memiliki empati; (5) fleksibel, terbuka, dan kooperatif dengan teman-teman (orang lain); dan
(6) mampu memecahkan masalah, mengambil keputusan, dan bertanggung jawab terhadap aktivitas-aktivitas atau kebutuhan-kebutuhannya.

Populasi penelitian ini adalah semua siswa kelas VII pada SMPN 1, SMPN 8, dan SMPN 35. Besar sampel untuk masing-masing sekolah (1 kelas), yakni SMPN 1 Makassar, 35 orang; SMPN 8 Makassar, 28 orang; dan SMPN 35 Makassar, 40 orang. Jumlah keseluruhan adalah 103 orang. Teknik pengambilkan sampel berdasar simple random sampling.

Teknik pengumnpulan data menggunakan skala, yakni skala pola asuh orangtua dan kemandirian anak. sedangkan teknik analisis data menggunakan analisis statistik deskriptif dan statistik inferensial.

\section{HASIL DAN PEMBAHASAN}

\section{Hasil}

\section{Analisis deskriptif}

Pola asuh yang digunakan orangtua saat ini dalam upaya meningkatkan kemandirian anak dirangkum dalam tabel 1 , berikut ini.

Tabel 1 Nilai Minimum, Maksimum, Mean, dan Std. Deviation

\begin{tabular}{lccccc}
\hline $\begin{array}{l}\text { Variabel } \\
\text { /Subvari } \\
\text { abel }\end{array}$ & $\mathrm{N}$ & $\begin{array}{c}\text { Rera } \\
\text { ta }\end{array}$ & SD & $\begin{array}{c}\text { Nilai } \\
\text { Mini } \\
\text { mum }\end{array}$ & $\begin{array}{c}\text { Nilai } \\
\text { Maxi } \\
\text { mum }\end{array}$ \\
\hline $\begin{array}{l}\text { P. Asuh } \\
\text { Otoriter }\end{array}$ & 103 & $\begin{array}{l}22,9 \\
029\end{array}$ & 3,75 & 13,00 & 31,00 \\
\hline P Asuh & 103 & 23,8 & 3,33 & 16,00 & 33,00 \\
Demokr & & 155 & 357 & & \\
\hline P.Asuh. & 103 & 23,0 & 4,04 & 16,00 & 32,00 \\
Permisif & & 777 & 797 & & \\
\hline P. Asuh & 103 & 22,3 & 4,40 & 14,00 & 31,00 \\
Penelant & & 204 & 858 & & \\
\hline P. Asuh & 103 & 25,2 & 3,87 & 14,00 & 32,00 \\
Positif & & 524 & 733 & & \\
\hline P. Asuh & 103 & 22,4 & 4,23 & 14,00 & 33,00 \\
Negatif & & 563 & 055 & & \\
\hline
\end{tabular}

Sumber: Skala Pola Asuh Orangtua

Berdasar data pada Tabel 1 dapat diketahui jenis pola asuh yang digunakan oleh orangtua saat ini secara berturut-turut: (a) Pola asuh positif $(25,2524)$; (b) Pola asuh demokratis $(23,8155)$; (c) Pola asuh permisif $(23,0777)$; (d) Pola asuh otoriter $(22,9029)$; (e) Pola asuh Negatif/tidak sehat $(22,4563)$, dan (f) Pola asuh penelantar $(22,3204)$. 
Jenis pola asuh orangtua yang dapat meningkatkan kemandirian anak dirangkum dalam Tabel 2.

\begin{tabular}{|c|c|c|c|c|c|}
\hline \multirow{3}{*}{ Model } & \multicolumn{5}{|c|}{$\begin{array}{l}\text { Hasil Pengolahan Data Korelasi Pola } \\
\text { Asuh Orangtua dan Kemandirian } \\
\text { Anak }\end{array}$} \\
\hline & $\begin{array}{l}\text { Unstandar } \\
\text { dized } \\
\text { Coefficien } \\
\text { ts }\end{array}$ & & $\begin{array}{l}\text { Standar } \\
\text { dized } \\
\text { Coeffic } \\
\text { ients }\end{array}$ & $\mathrm{T}$ & Sig. \\
\hline & $\mathrm{B}$ & Std. Err & Beta & & \\
\hline $\begin{array}{l}\text { (Cons } \\
\tan t)\end{array}$ & 119.470 & 7.445 & & 16.048 & .000 \\
\hline $\mathrm{X} 1$ & -.568 & .294 & -.169 & -1.931 & .056 \\
\hline $\mathrm{X} 2$ & .780 & .255 & .207 & 3.062 & .003 \\
\hline $\mathrm{X} 3$ & .909 & .329 & .293 & 2.765 & .007 \\
\hline $\mathrm{X} 4$ & -1.399 & .232 & -.491 & -6.042 & .000 \\
\hline $\mathrm{X} 5$ & 1.891 & .302 & .583 & 6.258 & .000 \\
\hline X6 & .715 & .270 & .241 & 2.649 & .009 \\
\hline
\end{tabular}

Berdasar data pada Tabel 2, nilai $t$ tertinggi (probabilitas $0,000<0,05$ ) digunakan untuk menentukan jenis pola asuh orangtua yang dapat meningkatkan kemandirian anak. Temuan penelitian menunjukkan bahwa jenis pola asuh orangtua yang memiliki korelasi yang kuat dalam meningkatkan kemandirian anak adalah pola asuh orangtua positif dan demokratis.

\section{Analisis inferensial}

Untuk mengetahui hubungan pola asuh orangtua dengan kemandirian anak, diajukan hipotesis yang berbunyi "Apakah ada hubungan antara pola asuh orangtua dan kemandirian anak?". Oleh karena yang diuji adalah hipotesis nihil maka terlebih dahulu diajukan hipotesis nihil $\left(\mathrm{H}_{0}\right)$ yang berbunyi, "Tidak ada hubungan antara pola asuh orangtua dan kemandirian anak". Hasil penghitungan statistik inferensial tentang hubungan antara pola asuh orangtua dan kemandirian anak dapat dilihat pada tabel 3 berikut ini.

Tabel 3 Hasil Pengolahan Data Hubungan antara Pola Asuh Orangtua dan Kemandirian Anak

\begin{tabular}{lrrrrr}
\hline Model & $\begin{array}{c}\text { Sum of } \\
\text { Squares }\end{array}$ & Df & $\begin{array}{c}\text { Mean } \\
\text { Square }\end{array}$ & F Sig \\
\hline Regression 9796.680 & 6 & 1632.78024 .77 & $.000^{\mathrm{b}}$ \\
\hline Residual & 6327.786 & 96 & 65.914 & \\
\hline Total & 16124.46 & 102 & & & \\
\hline Sumber: & $\begin{array}{l}\text { Skala Pola } \\
\text { Kemandirian Anak }\end{array}$ & Asuh & Orangtua
\end{tabular}

Data pada Tabel 3 menunjukkan bahwa terdapat hubungan yang positif dan signifikan antara pola asuh orangtua dan kemandirian anak.

\section{Pembahasan}

Hasil penelitian menunjukkan bahwa pola asuh yang digunakan orangtua dalam mengasuh, mendidik, dan membesarkan anak, tidak hanya satu, melainkan berbagai jenis pola asuh, bahkan semua jenis pola asuh digunakan.

Pola asuh positif, berada pada urutan pertama yang mampu meningkatkan kemandirian anak. Orangtua berkomunikasi, bertransaksi, berinteraksi dengan anak, ucapan dan tindakannya selalu mempertimbangkan layak/pantas, mendorong, konsisten, menyejukkan, merawat/memelihara, rileks, dan bertanggung jawab. Hal ini sesuai dengan pendapat James (2002) bahwa pola asuh orangtua positif, dapat meningkatkan keman-dirian anak.

Pola asuh otoritative (demokratis) berada pada urutan kedua. Orangtua berkomunikasi, bertransaksi, berinteraksi, ucapan dan tindakannya selalu bersikap rasional, bertanggung jawab, terbuka, obyektif, tegas, hangat, realistis, fleksibel, sehingga mampu menumbuhkan keyakinan, kepercayaan diri pada anak untuk mengambil keputusan terhadap aktivitas dan kebutuhannya. Hal ini dikukung oleh pendapat Santrock (2009), yang menyatakan bahwa pola asuh demokratis sangat baik dalam upaya meningkatkan kemandirian.

Pola asuh permisif berada pada urutan ketiga. Orangtua ketika berkomunikasi, bertransaksi atau berinteraksi dengan anak, selalu memberikan kebebasan pada anak, kurang menuntut tanggung jawab, melakukan pembiaran, sangat lemah dalam melaksanakan disiplin, dan kurang tegas dalam menerapkan peraturan-peraturan. Perilaku orangtua yang seperti ini menurut, Santrock (2009), Gordon (2000), menjadikan kepribadian anak tidak berkembang baik, termasuk menghambat kemandirian anak.

Pola asuh otoriter berada pada urutan keempat. Orangtua berkomunikasi, bertransaksi, berinteraksi dengan anak, cenderung menetapkan standar yang mutlak harus dituruti, menuntut kepatuhan, mendikte, kurang hangat, kaku dan keras, kurang memberi kepercayaan, menghukum. Hal ini didukung Papalia (2008), Santrock (2009), bahwa pola asuh otoriter, menjadikan anak tidak berkembang baik, karena merasa tertekan dan takut, sehingga tidak mampu mandiri.

Pola asuh negative berada pada urutan kelima. Ucapan dan tindakan ketika berkomu- 
nikasi, bertransaksi atau berinteraksi dengan anak, selalu mengkritik, melindungi berlebihan, tidak konsisten, selalu mendebat, serba mengatur, dan orangtua selalu mau dilayani. Hasil ini sesuai dengan pendapat, Gordon (2000) dan James (2002) yang menyatakan bahwa pola asuh negatif berdampak buruk bagi perkembangan kepribadian anak, termasuk menghambat kemandirian anak.

Pola asuh penelantar berada pada urutan keenam (terakhir). Orangtua berkomunikasi, bertransaksi/ berinteraksi selalu mengabaikan, menolak mendengar ungkapan perasaan dan ide anak, mementingkan diri sendiri, tidak memberikan kesempatan kepada anak untuk berbicara. Hasil ini didukung oleh Papalia (2008) dan Thalib (2010) yang menyatakan bahwa pola asuh penelantar memperlihatkan pola perilaku orangtua yang yang suka mengabaikan baik secara fisik maupun psikis, yang sangat menghambat perkembangan kemandirian anak.

Cara penerapan pola asuh orangtua positif sehingga dapat membuat anak mandiri: (1) pola asuh orangtua yang layak/pantas, bertujuan memperbaiki kesalahan anak disertai penjelasan logis, yang diterima anak tanpa tekanan; (2) pola asuh orangtua mendorong, tampak dalam ucapan dan tindakan mendorong anak mengerjakan sendiri tugas-tugasnya, baik di rumah maupun di luar rumah; (3) pola asuh orangtua konsisten, tampak dalam ucapan dan tindakan orangtua yang sama pada situasi dan kondisi yang sama, melatih anak menjadi tegas, tangguh, dan percaya diri; (4) pola asuh orangtua yang menyejukkan, tampak dalam ucapan dan tindakan orangtua yang lemah lembut dan menyenangkan; (5) pola asuh orangtua merawat, tampak dalam ucapan dan tindakan orangtua melalui bertujuan membantu anak merasakan belaian baik fisik maupun psikis, memperhatikan dan mendengar ucapan dan ungkapan perasaan anak, bergaul secara hangat dan saling menghormati; (6) pola asuh orangtua rileks, tampak dalam ucapan dan tindakan orangtua dalam suasana rileks, memberikan kebebasan kepada anak dalam berbicara, bertindak, dan beraktivitas secara santai tanpa merasa tertekan; (7) pola asuh orangtua bertanggung jawab, tampak dalam ucapan dan tindakan orangtua membelajarkan anak berani mengambil risiko dari kegiatannya, memberikan kepercayaan dan kebebasan melakukan aktivitas sesuai dengan kebutuhan, dan mengambil risiko dari aktivitas dan kebutuhannya itu.

Berdasarkan paparan pola asuh positif tersebut dapat disimpulkan bahwa kemandirian anak dapat meningkat, karena ucapan dan tindakan orangtua yang mempertimbangkan kelayakan, selalu mendorong, konsisten, menyejukkan, merawat, rileks, dan bertanggung jawab. Temuan ndirian anak dapat meningkat ini Temuan ini sejalan hasil penelitian Sunarty (2014) bahwa pola asuh orangtua dapat meningkatkan kemandirian anak adalah pola asuh positif. Temuan ini mendukung temuan Pratt (2004) yang menyatakan bahwa orangtua yang selalu memberi dorongan dan peluang serta bersikap rasional akan meningkatkan kemandirian anak, terutama ketika ia berusia di atas 20 tahun.

Pola asuh demokratis dapat meningkatkan kemandirian anak, karena ucapan dan tindakan orangtua: (1) memandang dirinya dan anak punya peran masing-masing; (2) memberikan tanggung jawab dan mendorong anak melakukan aktivitasnya sendiri; (3) berdialog, saling memberi dan menerima, mendengarkan keluhan, menghormati dan menghargai suatu keputusan; (4) bertindak secara obyektif, tegas, hangat dan penuh pengertian, tegas dalam pengambilan keputusan; (5) menumbuhkan keyakinan, kepercayaan diri pada anak, selalu menyemangati anak berbuat sesuai dengan kemampuan sendiri sesuai tahapan perkembangan; (6) mendorong anak mampu membuat keputusan sendiri, selalu mendorong melakukan pekerjaan dan kegiatannya sendiri, berani mengambil keputusan dan menanggung risiko dari keputusaanya tersebut.

Berdasar pada paparan pola asuh demokratis (otoritative) tersebut dapat disimpulkan bahwa ucapan dan tindakan orangtua yang memandang anak mempunyai hak dan kewajiban, tanggung jawab, saling menghargai dan menghormati, obyektif dan tegas, berani mengambil keputusan dengan segala risikonya, dapat meningkatkan kemandirian anak. Hasil ini sejalan dengan temuan penelitian Indrawati (2002) dan Komaruddin (2005) yang menyatakan bahwa anak yang tingkat kemandirian tinggi lebih banyak diasuh dengan pola asuh authoritative atau demokratis.

Hasil penelitian menunjukkan terdapat hubungan yang positif dan signifikan antara pola 
asuh orangtua dan kemandirian anak. Temuan ini sesuai Komaruddin (2005) yang meneliti kontribusi pola asuh orangtua terhadap kemandirian siswa, mengungkapkan ada hubungan yang positif dan signifikan kontribusi pola asuh dengan kemandirian anak; Indrawati (2002) tentang pengaruh pola asuh orangtua terhadap kemandirian remaja di SLTP Muhammadiyah 6 DAU Malang, memberikan hasil temuan ada pengaruh yang positif dan signifikan antara pola asuh orangtua dan kemandirian; Arifin (2008) meneliti tentang kemandirian anak dilihat dari pola asuh orangtua, memberikan kesimpulan bahwa terdapat hubungan yang berarti dan bermakna antara pola asuh orangtua dan kemandirian anak. Astuti (2009) meneliti tentang peranan pola asuh orangtua terhadap pembentukan kemandirian belajar peserta didik di SMA PGRI 1 Taman Kabupaten Pemalang Tahun Pelajaran 20082009 , menyimpulkan bahwa ada hubungan yang signifikan antara peranan pola asuh orangtua terhadap pembentukan kemandirian belajar peserta didik.

\section{SIMPULAN DAN SARAN}

Hasil penelitian menunjukkan bahwa: (1) Jenis pola asuh yang digunakan orangtua sekarang ini dalam memandirikan anaknya, secara berturut-turut: pola asuh positif, demokratis, otoriter, permisif, negatif/tidak sehat, dan penelantar; (2) Pola asuh yang dapat meningkatkan kemandirian anak, adalah pola asuh positif dan demokratis, dan (3) ada hubungan yang positif dan signifikan antara pola asuh orangtua dan kemandirian anak.

Disanrankan kepada para orangtua yang ingin meningkatkan kemandirian anaknya, sebaiknya menggunakan pola asuh orangtua positif dan demokratis dalam mengasuh dan membesarkan anaknya dalam kehidupan seharihari. Orangtua mulai membuka diri terutama ketika melakukan dialog untuk menciptakan hubungan yang baik dan harmonis agar anak dapat mengungkap permasalahan dan kebutuhannya, tanpa takut kepada orangtua.

\section{DAFTAR PUSTAKA}

Ali, M., \& Asrori, M. 2008. Psikologi Remaja: Perkembangan Peserta Didik. Jakarta: Bumi Aksara.
Arifin, Z. 2008. Kemandirian Anak Dilihat dari Pola Asuh Orangtua. Skripsi. Tidak Diterbitkan. Gorontalo: Universitas Negeri Gorontalo.

Astuti, P. W. 2009. Peranan Pola Asuh Orang Tua terhadap Pembentukan Kemandirian Belajar Peserta Didik SMK PGRI I Taman Kabupaten Pemalang Tahun Pelajaran 2008-2009. Skripsi. Tidak Diterbitkan. Tegal: FKIP UPS Tegal.

Darajat, Z. 1982. Perawatan Jiwa Anak. Jakarta: N.V. Bulan Bintang.

Desmita. 2009. Psikologi Perkembangan Peserta Didik: Panduan bagi Orang Tua dan Guru dalam Memahami Psikologi Anak Usia SD, SMP, dan SMA. Bandung: Remaja Rosdakarya.

Gordon. 2000. Parent Effective Traing: The Proven Program for Raising Responsible Children. New York: Random House Inc.

Indrawati. 2002. Pengaruh Pola Asuh Orangtua terhadap Kemandirian Remaja di SLTP Muhammadiyah 6 DAU Malang. Skripsi. Tidak Diterbitkan: Universitas Negeri Malang.

James, M. 2002. It's Never Too Late to Be Happy. Massachusetts: Addison-Wesley Publishing Company, Inc.

Komaruddin. 2005. Kontribusi Pola Asuh terhadap Kemandirian Siswa Kelas II SMA Negeri 1 Balapulang Kabupaten Tegal Tahun Pelajaran 2004/2005. Laporan Penelitian.

Marjohan. 2009. Kemandirian dalam Belajar Perlu Ditingkatkan. IPNU, IPPNU Tangkil Tengah, Senin, 16 Nopember 2009.

Papalia, D. E., Old., S. W., \& Feldman, R. D. 2008. Human Development: Psikologi Perkembangan. Edisi Kesmbilan. Jakarta: Kencana.

Pratt, M. W., Skoe, E .E., Arnold, M. L. 2004. Care reasoning development and family socialization patterns in later adolescence: A longitudinal analysis. International Journal of Behavioral Development, 28 (2), 139-147.

Santrock, J. W. 2007. Child Development. Edisi Kesebelas Jilid 1 Terjemahan Mila Rahmawati dan Anna Kuswanti. Jakarta: Penerbit Erlangga 
Santrock, J. W. 2009. Educational Psychology. Edisi Ketiga Buku 1. Terjemahan Diana Angelica. Jakarta: Salemba Humanika.

Sugito, 2013. Pendidikan untuk Pencerahan dan Pemandirian Bangsa. Yogyakarta: AshShaff.

Sunarty, K. 2014. Model Pola Asuh Orangtua untuk Meningkatkan Kendirian Anak. Disertasi. Tidak Diterbitkan. Makassar: Program Pascasarjana UNM

Sutopo, J. 2007. Fenomena "LKS" Meninggalkan Dampak Ketidakmandirian pada Siswa. Radar Bojonegoro, 13 Februari 2007.

Thalib, S. B. 2010. Psikologi Pendidikan Berbasis Analisis Empiris Aplikatif. Jakarta: Kencana Prenada Media Group.

Undang-Undang Republik Indonesia, No. 20. Tahun 2003 tentang Sistem Pendidikan Nasional. 2005. Jakarta: Balai Pustaka. 